\title{
Effect of Wood Smoke on the Quality of Smoked Fish
}

\author{
Kwaghvihi, O. B. ${ }^{1}$, Akombo, P. M. ${ }^{2} \&$ Omeji, S. ${ }^{3}$ \\ ${ }^{1,2}$ Department of Biological Sciences, College of Science, Benue State University, Makurdi. \\ ${ }^{3}$ Department of Fisheries and Aquaculture, College of Forestry and Fisheries, University of Agriculture, Makurdi.
}

DOI: $10.46382 / M J B A S .2020 .4207$

Smoke contributes to fish preservation by acting as an effective antioxidant and bactericidal agent as well as by providing a protective film on the surface of smoked fish. However, evidence suggests that smoked foods may contain carcinogens. The smoking process contaminates fish with polycyclic aromatic hydrocarbons (PAHs) and nitrosamines, which are known carcinogens that increase the risk of gastrointestinal cancer at frequent intake of smoked fish. This paper describes smoking process, composition of wood, preservation effect of smoke, effect of smoking on nutritive value of fish, health implication of wood smoke. It also describes possible ways to combat adverse effect of smoking as to obtain a good quality fish safe for human consumption.

Keywords: Smoke, Smoking, Smoked Fish, Polycyclic Aromatic Hydrocarbons (PAHs).

\section{Introduction}

Fish has been an important source of human food since ancient times, and contains high quality proteins, vitamins, and omega-3 fatty acids (Gang, 2013). However, fish is an extremely perishable of all staple commodities (Agbon et al., 2002). Soon after death, fish begins to spoil (Annune,1993). Preservation technique of smoking has been a method dated back to civilization as a means of preserving fish.

Smoking is the process of flavouring, cooking, or preserving food by exposing it to smoke from burning or smouldering material; most often wood. Smoking has been used for the preservation of food for centuries (Rahman, 2007; Petridis et al., 2012; Huong, 2014). Smoking gives the special colour and flavour to the fish (Duffes, 1999; Alcicek and Atar, 2010) and extends its shelf-life via the effects of dehydration, anti-microbial and anti-oxidant of the smoke compounds (Eyo, 2001; Goulas and Kontominas, 2005; Visciano et al., 2008; Pagu et al., 2013;). Smoking also changes the texture of product (Sigurgisladottir et al., 2001). Smoke is generated through incomplete combustion of wood (Muyela et al., 2012) and contains phenolic compounds, acids and carbonyls and the smoky flavor is primarily due to the volatile phenolic compounds. The relative concentration of phenolic compounds depends on the nature of the wood used in the smoking process (Sérot et al., 2004). Wood smoke is extremely complex and more than 400 volatiles have been identified (Guillen and Manzanos 1999). Wood smoke contains nitrogen oxides, polycyclic aromatic hydrocarbons, phenolic compounds, furans, carbonylic compounds, aliphatic carboxylic acids, tar compounds, carbohydrates, pyrocatechol, pyrogallols, organic acids, 
bases, and also carcinogenic compounds like 3:4 benzopyrene, polycyclic aromatic hydrocarbons are ubiquitous in the environment as pyrolysis product of organic matter. Their concentration in smoked fish can reach levels hazardous for human health, especially when the smoking procedure is carried out under uncontrolled conditions (Moret et al., 1999). Nitrogen oxides are responsible for the characteristic colour of smoked foods, whereas polycyclic aromatic hydrocarbon components and phenolic compounds contribute to its unique taste. These three chemicals are also most controversial from a health perspective (Mcllveen, and Valley, 1996; Cardinal et al., 2006).

\section{Fish Smoking}

Smoking is one of the oldest fish preservation methods. It consists in the application of wood smoke on food. (Varlet et al., 2007 and Bilgin et al., 2008). Smoking can inhibit the formation of toxins in products (Huong, 2014), reduce the growth of bacteria, due to lower water activity by smoking in combination with salting and drying which creates a physical surface barrier (Rorvik, 2000; Swastawati et al., 2000).

The spoilage and pathogenic microflora of smoked products are affected by density of smoke, concentration of active components of the smoke in combination with the salt content, and the time and temperature of smoking (Kolodziejska et al., 2002).

Smoking imparts aroma, taste and colour on processed fish (Visciano et al., 2008). Traditionally, fish is smoked in pits or on raised smoking "tables" where the control of heat is difficult and at times impossible. (Kumolu-Johnson et al., 2010).

Nowadays, shifting for high sensory quality product is the main purpose of smoking. The smoked products have higher moisture and lower salt content than in the past (Kolodziejska et al., 2002). The smoking process is characteristically a combination of salting, drying, smoking followed by vacuum, modified or controlled atmosphere packaging (Huong, 2014).

Depending on the way smoke gets into products, smoking can be categorized accordingly: the traditional technique - where the smoke is formed directly by burning chips or sawdust from firm wood in the oven (Stołyhwo and Sikorski, 2005; Visciano et al., 2008); or new technique - by using an electric field acts on the ionised smoke particles, which quickens the smoke deposition or by using commercial liquid smoke flavourings (Duffes, 1999; Martinez et al., 2007).

The quality of smoked fish is affected by raw material, salting method, brining concentration, condition processing, and composition of smoke, smoking method, smoke agents and storage conditions (Huong, 2014). 
Types of Smoking Process

\section{Hot Smoking}

Fish is smoked until cooked in order to obtain a product with extended shelf-life, since alternative preservation methods such as refrigeration are absent in remote fishing villages where most fish processing takes place (Aremu et al., 2013). Hot smoking is known as the traditional smoking method of smoking fish in the tropics.

Hot smoking entails the application of much more heat, through the burning of large quantity of fuel-wood. The products from hot smoking are tastier and have longer shelf lives (Aremu et al., 2013; Arason et al., 2014)). Hot smoking occurs within the range of 52 to $80^{\circ} \mathrm{C}\left(126-176^{\circ} \mathrm{F}\right)$. Within this temperature range, foods are fully cooked, moist and flavourful. High temperatures beyond the specified can lead to excessive shrinkage, buckle or even splitting. It also reduces yield, as well as other essential nutrients present in the fish (Myrvold, 2011).

Safe hot smoked fish requires at least 3.5\% water phase salt (WPS) and must have achieved an internal product temperature of at least $145^{\circ} \mathrm{F}\left(62.8^{\circ} \mathrm{C}\right)$ for at least 30 minutes. This prevents the production of toxins by Clostridium botulinum (Huong, 2014). Additionally, water activity (aw) of hot smoked fish products must be less than 0.85 to make products stable at room temperature (Arason et al., 2014).

The hot smoking of fish includes five steps: surface drying, smoking, drying, heating/ cooking and cooling. Cooling the fish to lower than cooking temperature is carried out immediately in the smoke house. Then, cooling down to less than $38^{\circ} \mathrm{F}\left(3.3^{\circ} \mathrm{C}\right)$ as quickly as possible but not in the smokehouse and keeping products at that temperature to reduce the growth of food poisoning bacteria until consumption (Huong, 2014).

\section{Cold Smoking}

Cold smoking is practiced in advanced countries where alternative means of preserving the fish such as refrigeration is available. Cold smoking is primarily to improve the flavor of the fish and retain its nutritive value (Eyo, 2001). Cold smoking is a smoking method where the temperature is maintained between 20 to $30^{\circ} \mathrm{C}\left(68-86^{\circ} \mathrm{F}\right)$. In this temperature range, fish take on a smoked flavor, but remain relatively moist (Myrvold, 2011; Huong, 2014).

Arason et al., (2014) suggests that the relative humidity during cold smoking should be remained in the range of $75-85 \%$. Vacuum packed and chilled storage should be followed by cold smoking because product is not completely preserved (Rørvik, 2000). 


\section{Composition of Wood Smoke}

\section{Wood Composition}

Wood smoke is produced by smouldering chips or sawdust of firm wood below the fish in the smokehouse (Visciano et al., 2008). The composition of wood has an effect to the taste of the final product. Wood used as a smoke source is hardwood such as: beech, hickory, oak or fruitwood as apple, pear jackfruit, etc (Huong, 2014). Hard woods consist of three main components: cellulose, hemicellulose and lignin (Hui et al., 2001) in a 2:1:1 ratio and represent $95 \%$ of dry matter (Codex Alimenterius Commission, 2008). Cellulose and hemicellulose are the basic structural material of the wood cells; lignin acts as a kind of cell-bonding glue. Cellulose and hemicellulose are aggregate sugar molecules; when burnt, they effectively caramelize, producing carbonyls, which provide most of the colour components and sweet and sweet, flavoury and fruity aromas. Lignin, a highly complex arrangement of interlocked phenolic molecules, also produces a number of distinctive aromatic elements when burnt, including smoky, spicy and pungent compounds such as guaiacol, phenol, and syringol and sweeter scents such as the vanilla- scented vanillin and clove- like isoeugenol. Guaiacol is the phenolic compound most responsible for the "smokey" taste, while syringol is the primary contributor to smoky aroma. Wood also contains small quantities of proteins, which contribute roasted flavours. Many of the odors are unsuitable, dissipating after a few weeks or months. Different species of trees have different ratios of components; various types of wood do impact a different flavor to food (Hui et al., 2001; Jakabsone and Bartkevics, 2006). Another important factor is the temperature at which the wood burns. High temperature fires see the flavour molecules broken down further into unpleasant or flavourless compounds. The optimal conditions for smoke flavor are low, smouldering temperatures between 570 and $750^{\circ} \mathrm{F}\left(299\right.$ and $\left.399^{\circ} \mathrm{C}\right)$. This is the temperature of the burning wood itself, not of the smoking environment which uses much lower temperatures. Woods high in lignin content tend to burn hot, to keep them smouldering requires restricted oxygen supplies or a high moisture content. When smoking using chips or chunks, the combustion temperature is often raised by soaking the pieces in water before placing them on a fire (Hui, et al., 2001).

\section{Chemical Composition of Wood Smoke}

Smoke consists of liquid and solid particulates suspended in a gaseous phase. Particles in the smoke, generally of a size of $0.2-0.4 \mu \mathrm{m}$ (or as low as 0.05 to $1 \mu \mathrm{m}$ (Guillen et al., 2000), are estimated to constitute $90 \%$ of its overall weight. The chemical composition of smoke is complex and more than 300 components have been identified (Simko, 2005). Many 
chemical contaminants are formed during the combustion of fuel both in the smoking and in the direct drying process. Examples include polycyclic aromatic hydrocarbons (PAHs), dioxins, formaldehyde, nitrogen and sulfur oxides (relevant for formation of e.g. nitrosamines). Furthermore, heavy metals are also found in combustion gases (Codex Alimenterius Commission, 2008). The types and amount depend on the fuel used, the temperature and possible other parameters (Nielsen and Illerup, 2003).

Polycyclic aromatic hydrocarbons (PAHs) are carcinogenic and environmental contaminants (Varlet, et al., 2011), which can be found in food (Muyela et al., 2012). Contamination of foodstuffs by PAHs can occur at source through atmospheric deposition on crops, or from preservation of food by drying and cooking procedures. This contamination is enhanced during smoking and intense thermal processing (Chen and Chen, 2001). During intense thermal processing the contamination occurs by direct pyrolysis of food nutrients (Orecchio and Papuzza, 2008). The PAHs are also deposited from smoke produced through incomplete combustion of different thermal agents (Muyela et al., 2012). Smoked foods have been known for several decades, to be a source of PAHs especially benzo(a)pyrene. In the smoking process, PAHs are generated during smoke production by wood pyrolysis. Because of their lipophilic properties, PAHs can accumulate in the lipid fraction of food products and are not easily extracted from food with a high fat content. Moreover, many analytical strategies have been developed to detect and measure these compounds such as de-fatting, which are especially used during the extraction step. Accelerated Solvent Extraction (ASE), Solid-Phase Extraction (SPE) clean-up on selected cartridges, and saponification has been developed in order to avoid lipids suspected of disrupting the analysis. All the studies dealing with $\mathrm{PAH}$ analysis in smoked food have been carried out with a single detector and GC/MS and HPLC/FD are the two main analytical methods for their measurement at low levels (Varlet et al., 2011).

\section{Preservation Effect of Smoke}

Smoke contributes to fish preservation by acting as an effective antioxidant, bacteriostatic and bactericidal agent as well as by providing a protective film on the surface of smoked fish. Smoking kills food poisoning and spoilage bacteria or renders them harmless by altering the chemistry of the environment these spoilage organisms need to grow (Hilderbrand, 2001). Smoked foods are generally better preserved and protected against insect's infestation than untreated products (Crynen, 2007). Smoking preserves fish by drying, cooking and depositing natural wood-smoke chemicals like tars, phenols and aldehydes all of which have powerful bactericidal action and prevent the growth of other 
microorganisms on the flesh of the fish. The phenolic fraction of wood smoke is said to possess the highest inhibiting ability on bacteria (Aremu, et al., 2013). The smoke determines the colour which is one of the qualities that attracts consumers. It imparts aroma, taste and colour on processed fish (Kumolu-Johnson, 2010). Compounds such as carbonyls and acids; as well as phenolic fractions contribute significantly in the overall flavor of smoked fish. The colour of smoked fish is relatively not independent on the method as well as the type of wood or agricultural waste used in smoking the fish. The colour ranges from black, dark brown, golden brown or light brown to dirty white. Al- though preservation methods for fish and products are often used in order to make the fish safer and to prolong its shelf- life, the determination of some proximate parameters such as moisture, ash, lipid and protein contents are necessary so as to ascertain that they meet the requirements of food regulations and commercial specifications (Aremu, et al., 2013).

\section{Effect of Smoking on Nutritive Value of Fish}

Fish is smoked until cooked in order to obtain a product with extended shelf-life, since alternative preservation methods such as refrigeration are absent in remote fishing villages where most fish processing takes place. Hot smoking is the traditional methods of fish smoking in the tropics. Hot smoking entails the application of much more heat, through the burning of large quantity of fuel-wood. (Aremu, et al., 2013). This process has effect on the nutritive value of fish, and is also responsible for significant modifications of the organoleptic properties of fishmeal (Kjallstrand and Petersson, 2001).

Some studies have reported reductions in the quality of protein as a result of smoking. The loss in available lysine may vary from $6-33 \%$ at $25^{\circ} \mathrm{C}$ to $53-56 \%$ at $40{ }^{\circ} \mathrm{C}$ during hot smoking and a $25 \%$ loss of available lysine on the surface and a $12 \%$ loss at the center of hot smoked fish (Akinwumi, 2014). Akande, Oladosu, and Tobor (1998) observed that lysine reduction was directly proportional to the temperature and duration of smoking. The lysine loss is partly attributed to high temperature effect as a Millard reaction. This reaction involves the amino acids with sugars. These changes are necessary to give the characteristic golden- brown colour of smoked fish. Losses in other amino acids such as arginine, histidine and a decline in net protein utilization (NPU) have been observed in smoked fish. A number of chemical reactions may take place during heat treatment including decomposition, dehydration of serine and threonine, loss of sulphur from cysteine oxidation of cystane and methionine, cyclization of glutamic and aspartic acids and threonine.

However, the positive effect of heat intensity on the shelf-life of smoked product has been reported by several researchers. $\mathrm{CO}_{2}$ is reported to have an important effect on microbial 
growth, exerting a selective inhibitory action. Akinwumi, (2014) in his study on the Effects of Smoking and Freezing on the Nutritive Value of African Mud Catfish, (Clarias gariepinus) observed that, the proximate values of the smoked fish samples in all the parameters studied were statistically significant to those in the fresh fish samples (control). There was significant increase in the protein level in smoked catfish, when compared with the frozen catfish; therefore, he suggests that protein was not lost during smoking. This finding is in agreement with the observations of Puwastien et al., (1999). Similarly, Fapohunda and Ogunkoya (2006) reported that smoke drying methods increased the protein, ash and fat contents of C. gariepinus. Salan, et al., (2006) observed decrease of moisture, carbohydrate, lipid, potassium and vitamin C contents and increase of protein, ash, crude fibre, phosphorus and iron contents in smoked C. gariepinus. The authors further noted that the increase in the ash content in the smoked fish was due to the loss of humidity and that the significant reduction in the moisture content when the fish was smoked was as a result of the loss in moisture during hot smoking. The components in the wood/charcoal via pyrolysis are broken down in the process of burning to form smoke, thus it gives the fish a unique aroma and, improves its taste and colour because of the presence of a range of phenolic compounds, nitrites and formaldehyde present in the smoke (Akinwumi, 2014).

The control of the organoleptic characteristics can be of real interest to processors who want to adapt their products to consumers demand. The method of smoke generation and the smoking process used have a considerable influence on the sensory characteristics of smoked fish, particularly on smoke flavour perception (Cardinal et al., 2006).

\section{Health Implication of Wood Smoke}

Wood combustion is typically inefficient and a multitude of partially oxidized organic chemicals are generated in wood smoke. Wood smoke contains a large number of chemicals, many of which have been associated with adverse health impacts. Examples include polycyclic aromatic hydrocarbons (PAHs), dioxins, formaldehyde, nitrogen and sulfur oxides (relevant for formation of e.g. nitrosamines). Furthermore, heavy metals are also found in combustion gases. The types and amount depend on the kind of wood used, the temperature, the method used for developing the smoke, the water content in the wood and possible other parameters (Nielsen and Illerup, 2003; Naeher et al., 2005). There has been considerable evidence which suggested that smoked foods may contain traces of compounds with mutagenic or carcinogenic potential (Muyela et al., 2012). The smoking process contaminates fish with polycyclic aromatic hydrocarbons (PAHs), especially benzo[a]pyrene (Simko et al., 2002) and nitrosamines, which are known carcinogens, so, in 
theory; consuming smoked food increases the risk of gastrointestinal cancer. Hence, safety of food is a growing concern worldwide and PAHs residues if present in food above the maximum residual limit (MRL) pose a serious threat to the public health (Muyela et al., 2012). Therefore, there are strong pressures on chemical safety for smoked products from the EU institutions. Thus the Codex Alimentarius Commission on contaminants in food, at its 29th session from 16 to 20 April 2007 established a reflection on reducing levels of Polycyclic Aromatic Hydrocarbons (PAHs) in food dried and smoked. In addition, the EU Regulation $1881 / 2006 / E C$ on the content of PAH in smoked products has been amended (European Union (EU), 2011), and in September 2014, these levels were lowered from 5 to $2 \mu \mathrm{g} / \mathrm{kg}$ for benzo[a]pyrene and from 30 to $12 \mu \mathrm{g} / \mathrm{kg}$ for PAH4 (Bourgeois, et al., 2014)

The decision of the Codex Alimentarius Commission is very important for the activity of the smoked fish industry because it will lead to the questioning of certain practices and the necessity of an absolute control of processes to produce smoked fish presenting both excellent organoleptic and all guarantees in terms of food safety.

\section{Possible Ways to Combat Adverse Effect of Smoking}

Contamination of food with PAH via environmental contamination should be controlled either by source-directed measures like filtering the smoke from relevant industries (e.g., cement work, incinerator and metallurgy) and limiting the exhaust of PAH from cars. Good agricultural practices (GAPS), including harvesting of shellfish from contaminated water should be avoided. The Joint FAO/WHO Expert Committee on Food Additives (JECFA) conducted a comprehensive risk assessment of PAH in 2005 (WHO 2006). JECFA recommended keeping the content of these contaminants in food as low as reasonably achievable during drying and smoking processes, e.g. by replacing direct smoking (with smoke developed in the smoking chamber, traditionally in smokehouses) with indirect smoking (liquid smoke) (JECFA, WHO, 2006; CAC, 2008). Eyo, (2001) suggested removal and discarding of the outer layers of the product as measure of minimizing PAHs, since polycyclic aromatic hydrocarbons are concentrated on the surface layer of the product.

During the production of liquid smoke, some steps allow to reduce the PAH rate in the final liquid smoke whereas it is not easy to control the PAH rate during traditional smoke generation. Moreover, the storage of liquid smoke in polyethylene flasks can also reduce PAHs concentration (Guillen et al., 2000). Nevertheless, the legal threshold of benzo(a)pyrene is lower for the smoke flavourings additives than for the other smoking procedures. Concerning smoking techniques applying wood pyrolysis, the modern facilities have allowed separating the smokehouse and the wood smoke generator. However, even if 
food is placed in a separate chamber from the wood smoke generator and even if wood smoke is cleaned by various electrostatic filters or smoke washing, PAHs occurrence can be minimized but not totally controlled and suppressed. A better knowledge of smoking parameters, particularly smoke production parameters could allow to optimize the organoleptic characteristics of the smoked food and to obtain safety products (Varlet, et al., 2007).

\section{Conclusion}

There is need for regular monitoring of the levels of PAHs in smoked fish due to the mutagenic and carcinogenic potential of these compounds. Smoked fish has being a common food and the smoking processes such as combustion temperature, duration of smoking, fuel sources as well as environmental contaminants differentiates organoleptic properties that are much appreciated by consumers.

\section{References}

Agbon A.O., Ezeri G.N.O., Ikenwiewe B.N., Alegbleye N.O., and Akomolade D.T. (2002). A comparative study of different storage methods on the shelf life of smoked current fish. Journal of Aquatic Sciences, 17(2): 134-136.

Akande, G. R., Oladosu, O. H., and Tobor, J. G., (1998). A Comparative technical and economic appraisal of fish smoking: Two traditional ovens and a new Improved Magbon-Alade oven. FAO Fisheries Report, 574: 70-75.

Akinwumi, F. O., (2014). Effects of Smoking and Freezing on the Nutritive Value of African Mud Catfish, Clarias gariepinus Burchell, 1822. Journal of Agricultural Science; 6 (11): $1916-9760$.

Alcicek, Z., and Atar, H. H. (2010). The effects of salting on chemical quality of vacuum packed liquid smoked and traditional smoked rainbow trout (Oncorhyncus mykiss) fillets during chilled storage. Journal of Animal and Veterinary Advances, 9: 2778-2783.

Annune P.A., (1993). Fish Processing and Preservation Techniques. Paper Presentation at the 9th Monthly Review Meeting of the Kebbi State ADP Birnin Kebbi.

Aremu, M. O., Namo, S. B., Salau, R. B., Agbo C. O. and Ibrahim H. (2013). Smoking Methods and Their Effects on Nutritional Value of African Catfish (Clarias gariepinus). The Open Nutraceuticals Journal, 6: 105-112.

Duffes, F. (1999). Improving the control of Listeria monocytogenes in cold smoked salmon. Trends in Food Science and Technology, 10: 211-216. 
Eyo, A.A., (2001). Fish Processing Technology in the Tropics. A Text Book, University of Ilorin Press. 403pp.

Fapohunda, O. O., and Ogunkoya, M. (2006). Effect of smoke-drying on the proximate composition of Tilapia zillii, Parachanna obscura and Clarias gariepinus obtained from Akure, Ondo-State, Nigeria. Animal Research International, 3(2), 478-480.

Gang m., (2013). Changes In The Quality And Yield Of Fish Fillets Due Temperature Fluctuations During Processing. Dalian Ocean University. China.

Goulas, A., and Kontominas, M. (2005). Effect of salting and smoking-method on the keeping quality of chub mackerel (Scomber japonicus): biochemical and sensory attributes. Food Chemistry, 93: 511-520.

Guillen, M.D., and Manzanos, M.J. (1999). Study of the components of a solid smoke flavouring preparation. Food Chemistry, 55 (3), 251-257.

Guillén, M.D., Sopelana, P., Partearroyo, M.A., (2000). Polycyclic aromatic hydrocarbons in liquid smoke flavorings obtained from different types of wood. Effect of Storage in Polyethylene Flasks on their Concentrations. Journal of Agriculture and Food Chemistry, 48: 5083-5087.

Jãkabsone, I., Bartkevics, V. (2006). Changes in the Content of Polycyclic Aromatic Hydrocarbons Present in Oils and Meat under Impact of Technological Processes. Study was supported by the Ministry of Agriculture of Latvia, Grant contract no. 270606/S318.

Kjällstrand, J., and Petersson, G. (2001). Phenolic antioxidants in wood smoke. The Science of the Total Environment, 27: 69-75.

Hattula, T., Elfving, K., Mroueh, U., and Luoma, T. (2001). Use of Liquid Smoke Flavouring as an Alternative to Traditional Flue Gas Smoking of Rainbow Trout Fillets (Oncorhynchus mykiss). Lebensmittel- Wissenschaft und-Techologies, 34: 521-525.

Hilderbrand, K. S. Jr. (2001). Fish Smoking Procedures for Forced Convection

Smokehouses. Oregon State University Extension Sea Grant Program Hatfield Marine

Science Center Newport, Oregon 97365.

http://seagrant.orst.edu/sgpubs/onlinepubs/i01001.pdf

Huong, D.T.T. (2014). The effect of smoking methods on the quality of smoked Mackerel. United Nations University Fisheries Training Programme, Iceland [final project]. http://www.unuftp.is/static/fellows/document/huong13prf.pdf

Moret, S, Conte, L, Dean, D. 1999. Assessment of polycyclic aromatic hydrocarbon content of smoked fish by means of a fast HPLC/HPLC method. Journal of Agriculture and Food Chemistry 47:1367-1371. 
Muyela, B., Shitandi, A. and Ngure, R. (2012). Determination of benzo[a]pyrene levels in smoked and oil fried Lates niloticus. International Food Research Journal, 19(4): 1595-1600.

Pagu, I., Nistor, C., Măgdici, E., Hoha, G., Albu, A., and Păsărin, B. (2013). Research regarding the influence of age and corporal weight on efficiency at smoking and chemical composition of smoked Rainbow trout. University of Agricultural Sciences and Veterinary Medicine Iasi, 216-220.

Petridis, D., Zotos, A., Kampouris, T., and Roumelioti, Z. (2012). Optimization of a steaming with liquid smoke smoking process of Mediterranean mussel (Mytilus galloprovincialis). Food Science and Technology International, 19: 59-68.

Puwastien, P., Judpresong, K., Kettwan, E., Vasanachitt, K., Naknganong, Y., and Bhattacharjee, L. (1999). Proximate composition of raw and cooked Thai fresh water and marine fish. Journal of Food Composition and Analysis,12: 9-16. http://dx.doi.org/10.1006/jfca.1998.0800

Rørvik, L. M. (2000). Listeria monocytogenes in the smoked salmon industry. International Journal of Food Microbiology, 62, 183-190.

Salan, O. E., Juliana, A. G., \& Marilia, O. (2006). Use of smoking to add value to Salmoned trout. Brazillian Archives of Biology and Technology, 49(1): 57-62.

Sigurgisladottir, S., Sigurdardottir, M., Ingvarsdottir, H., Torrissen, O., and Hafsteinsson, H. (2001). Microstructure and Texture of fresh and smoked Atlantic salmon, Salmo salar L., fillets from fish reared and slaughtered under different conditions. Aquaculture Research, $32,1-10$.

Sérot T., Baron R., Knockaert C. and Vallet J.L., (2004). Effect of smoking processes on the contents of 10 major phenolic compounds in smoked fillets of herring (Cuplea harengus). Food Chemistry; 85(01): 111-120.

Varlet V., Serot T., Knockaert C., Cornet J., Cardinal M., Monteau F., Bizec B.L., and Prost C. (2007). Organoleptic characterization and PAH content of salmon (Salmo salar) fillets smoked according to four industrial smoking techniques: Journal of the Science of Food and Agriculture. 87(5): 847-854.

Visciano, P., Perugini, M., Conte, F., and Amorena, M. (2008). Polycyclic aromatic hydrocarbons in farmed rainbow trout (Oncorhynchus mykiss) processed by traditional flue gas smoking and by liquid smoke flavourings. Food and Chemical Toxicology, 46: 1409-1413.

Myrvold, N. (2011). Modernist Cusine. The Cooking Lab. P.143. ISBN 978-0-9827610-0-7. 